\title{
ORIGINALITY AND INFLUENCE: CHARLES GRÖLL'S ROLE IN THE INVENTION OF THE DOUBLE-ACTION HARP
}

\begin{abstract}
Sébastien Erard (I752-I83I) is widely considered the father of the modern harp, $\mathcal{S}$ in part because of his invention (c. 1786) of the forked discs that shorten the vibrating length of the strings by a semitone, but above all for his I8Io invention of the double action, a mechanical system that allows the harpist to play in all keys and which has been used on virtually all concert pedal harps for the past two centuries. ${ }^{\mathrm{I}}$ However, Erard's double-action harp model was similar to that of the Warsaw-born artist and inventor Charles Gröll (1770-1857), who had submitted his patent in I807, almost three years before Erard. Moreover, Erard bought the rights to Gröll's patent prior to finalising his own. For these reasons, some critics since the nineteenth
\end{abstract}

I For their assistance with my research, I wish to thank Joanna Gul (Wrocław), Tomasz Kołodziej (Warsaw), Sean Bottomley (Toulouse), Christine MacLeod (Bristol) and Jacqueline Letzter (Nice).

The forked discs are present on Erard's first instrument, today preserved in the Gaveau-Erard-Pleyel archives. In a 1959 inventory of the Erard firm's collections, this harp is identified as a 'prototype' and 'first attempt at a pedal harp, by Sébastien Erard' ('premier essai de harpe à pédales, par Sébastien Erard'); see 'Actif immobilier appartenant à la maison Erard', Gaveau-Erard-Pleyel archives, D.2009.I.I762. It is difficult to date this instrument with any degree of precision. In the report of the Institut de France in I8I5, we read: 'The first attempts Sébastien Erard made, in Paris, to improve the harp, date to around I786' ('Les premiers essais que Sébastien Erard fit, à Paris, pour perfectionner la harpe, datent environ de I786'). However, the author of the same document continues: 'On his first harps, made around 1789' ('Dans ces premières harpes, fabriquées vers 1789 '), which implies that there was a period of experimentation between 1786 or 1787 and 1789 , as Erard only began selling his harps to the public around I789; see Rapport fait le I7 avril I8IS aux Ière et 4ème classes (présentement Académie Royale des Sciences et Académie Royale des Beaux-Arts) de l'Institut de France sur une nouvelle harpe de l'invention de Sébastien Erard, p. 8, n. I. According to Fétis, Erard began to build harps around 1786; François-Joseph Fétis, Biographie universelle des musiciens et bibliographie générale de la musique, 2nd ed., Paris 1878, vol. III, p. I46. In an I842 document, Pierre Erard dated his uncle's first forays into harp building to the period 1787 to 1790 ; see Gaveau-Erard-Pleyel archives, D.2009.I.86. Erard's invention of the forked discs was patented only in 1794 in London. For a comprehensive history of Erard's contributions to both the harp and the piano, see The history of the Erard piano and harp in letters and documents, 1785-1959, eds. Robert Adelson, Alain Roudier, Jenny Nex, Laure Barthel and Michel Foussard, 2 vols., Cambridge 2015, hereafter abbreviated as HEPH. 
century have called into question Erard's claim to authorship of the double-action harp, suggesting that Gröll was its true inventor. ${ }^{2}$ The purpose of the present article is to clarify Gröll's role by placing it in the context of the evolution of Erard's ideas, established by a number of sources that have recently come to light.

\section{EARLY DOUBLE-ACTION SYSTEMS, FROM COUSINEAU TO ERARD}

The double-action harp is the culmination of an evolutionary process that began in 1697 when the luthier Jacob Hochbrucker (I673-1763) of Donauwörth in Bavaria improved the earlier diatonic harp by linking a set of pedals to a mechanism of single metal crutches on the neck of the harp. ${ }^{3}$ When one depresses a pedal, the pedal pulls on a rod hidden in the column of the harp (on the earliest pedal harps the rods passed through the soundbox). This rod operates the crutch mechanism, shortening the vibrating length of all of the strings sharing the same note name in all of the octaves. The flats become natural, and the naturals become sharp. There are therefore seven pedals (and seven rods hidden in the column) for the seven notes of the scale. The action of this earliest type of pedal harp is called 'single' because the open string can only be modified by a single semitone, by depressing each pedal one time.

The musical potential of the single-action harp remained limited compared with that of keyboard instruments. By only producing two notes per string - that of the open string and that of the string shortened by the depression of a pedal - the harp could not modulate in keys exceeding three flats or four sharps, except in certain short passages using enharmonic notes. These very limitations may have been responsible for eighteenth-century composers' relative disinterest in developing a more

2 Gröll's patent, as well as its purchase by Erard, was known in the nineteenth century, and discussed in print at least until Gröll's death in I857 (see below). Mike Baldwin was the first modern scholar to take note of Gröll's harp patent, in his article 'The inventor of the double-action pedal harp with fourchettes: Gröll versus Erard', FoMRHI Quarterly 79 (I995), pp. 29-34, revised in 2009 at http://www.harpspectrum. org/historical/Erard\%2oversus\%20Groll.shtml, accessed 2 July 20I8. The Polish harpist Anna Sikorzak-Olek also published an electronic article on the subject, summarizing many of Baldwin's conclusions but lacking any references to sources consulted; see her 'Karol Groll, the forgotten Polish inventor of the modern harp", http://www.harpspectrum.org/historical/Karol_Groll_inventor_of_the_modern_harp. shtml, accessed 2 July 20I8. Baldwin suggests that Gröll's patent shows that 'Erard's harp developments were not as original as commonly thought'. As a result of Baldwin's article, Erard's reputation is often challenged. For example, in their display texts, the Metropolitan Museum of Art in New York now credits the invention of 'the double action of the pedals' to 'Charles Groll/S. Erard (I807/Io)'; see https://www. metmuseum.org/art/collection/search/50399I, accessed 2 July 2018.

3 Simon Hochbrucker, son of Jacob, wrote that his father invented the pedal harp in I697. See Simon Hochbrucker, preface to Recueil d'ariettes choisies Op. 2, Paris [s.d.]. The earliest dated Hochbrucker harp, preserved in the Kunsthistorisches Museum in Vienna (SAM 565), was made in 1720 , and as a result some mistakenly consider this to be the date of the invention itself. However, there is no evidence that the 1720 harp was Hochbrucker's first instrument. Moreover, the specificity of the 1697 date, as well as the fact that the attribution of the invention to Jacob Hochbrucker remained unchallenged in late eighteenth-century France, lends credence to Simon Hochbrucker's account. 
significant repertoire for the harp. The race to invent a practical chromatic harp that was able to play in all major and minor keys therefore became one of the great technological challenges in instrument making in the late eighteenth and early nineteenth centuries.

The story of the double-action harp began in 1782 , when the Parisian harp maker Georges Cousineau (1733-1800) built a fourteen-pedal instrument, the first harp to be able to sound three notes per string (flat, natural and sharp), thus allowing it to be played in all keys. ${ }^{4}$ Cousineau's fourteen-pedal harp features two rows of seven pedals, each connected to a distinct row of crutches found on the neck of the instrument. The action is 'double' because the harpist can raise the pitch of the open string twice: by using the bottom row of pedals to change the notes from flat to natural, and then by using the top row to raise the note an additional semitone, from natural to sharp. Cousineau's fourteen-pedal harp failed to gain a following, probably because its complex mechanism was invented before there was a strong musical demand for such an instrument.

Sometime after 1796, Erard bought the prototype of Cousineau's fourteen-pedal harp in order to study it and to remove it from circulation. He was therefore aware of the possibility of using a double row of mechanism on the neck of the harp even at this early date, but sought an approach to the double action that would be simpler and more elegant than one based on two rows of forked discs. Indeed, even today when one looks at Cousineau's fourteen-pedal harp, one is most struck not by the number of pedals, but rather by the double row of the complicated crutch mechanism on the neck of the harp, consisting of hundreds of metal pieces requiring careful regulation (see Figure I). Harp makers at the end of the eighteenth century were ambivalent about showing off their mechanisms in this fashion, as the prevailing system à crochets used by Jean-Henri Naderman (1734-99) and other luthiers was discreet in appearance. Cousineau adopted a rather ostentatious approach: even apart from his fourteen-pedal harp, many of his other instruments displayed the intricacies of the interior levers through glass windows mounted on the neck of the harp. Erard's approach was more conservative, and on his earliest harps the forked discs are hidden behind the neck plate, which lets the two prongs of the forks pass through semicircular cut-outs in the brass. It was only around 1800 that Erard abandoned these interior forks and began mounting the discs more visibly on the outside of the neck plate, where they are more easily accessible for adjustments.

4 Robert Adelson, Alain Roudier and Francis Duvernay, 'Rediscovering Cousineau's fourteen-pedal harp', Galpin Society Journal 63 (2010), pp. I59-180. The prototype of Cousineau's fourteen-pedal harp is today conserved in a private collection. 


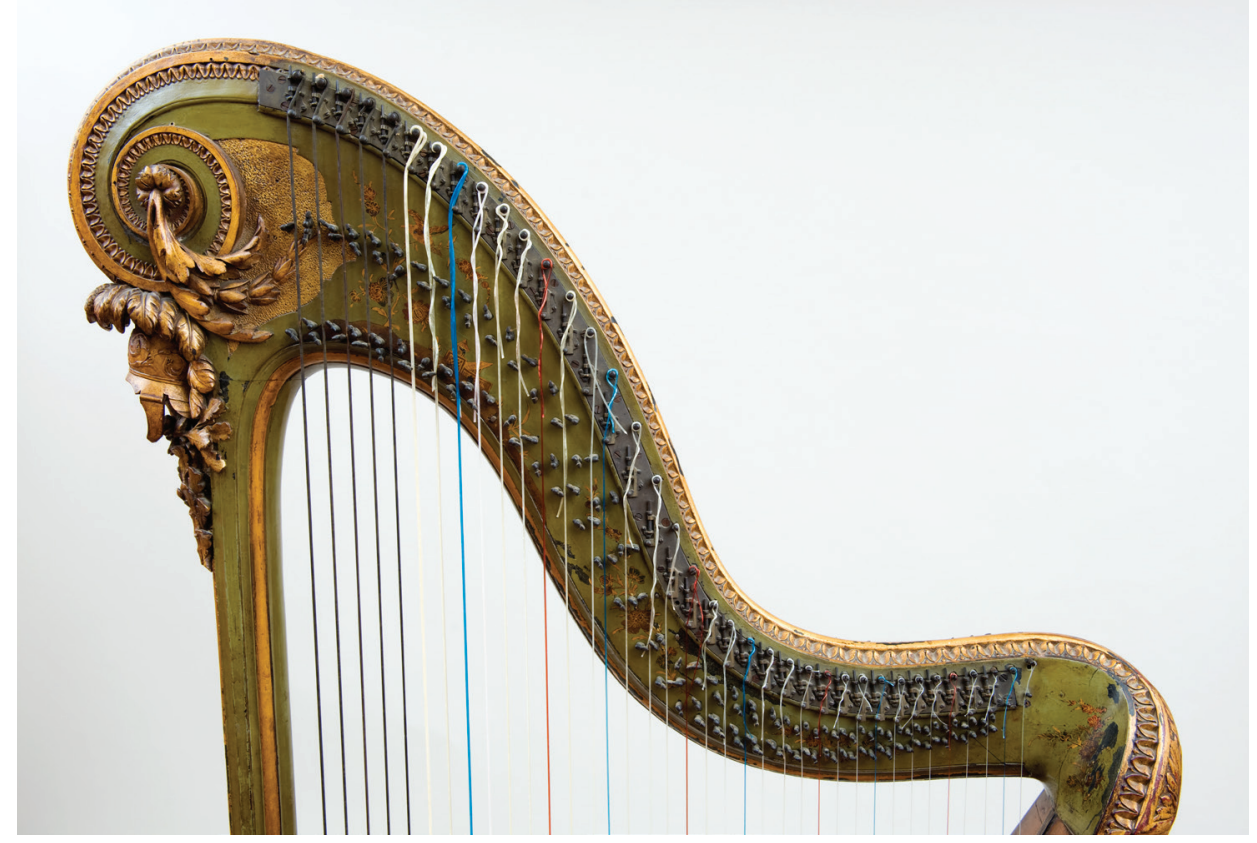

Figure I. Georges Cousineau (I733-I800), double-action harp with fourteen pedals (I782). View of neck showing the double row of Cousineau's crutch mechanism. Private collection. Photo: Robert Adelson.

In I80o, Erard applied for a patent for his first double-action harp, which avoided adding any visible string-shortening mechanism whatsoever to the neck of the harp. ${ }^{5}$ Instead, the pitch is altered by increasing the string tension: the pins around which the strings are wound are linked to the pedals by rods, and when one depresses a pedal, the corresponding strings roll around their pins just enough to sharpen the pitch of the strings by a semitone. ${ }^{6}$ Erard's harp also featured a pedal box consisting of a single row of seven pedals each with two cutaway notches, a radical yet elegant simplification of Cousineau's fourteen-pedal system. This double-notched pedal box was the perfect match to the progressive tightening of the open string: the first downward pedal motion could produce the initial tightening of the string, and

5 The Erards applied for this French patent on 7 July I800, and it was granted on 27 April I802. On I6 May I80I they applied for an English patent for the same invention, which they were granted on I6 June I8OI (patent no. 2502). Subsequent improvements to the invention were protected by a second English patent (24 April I802) and a second French patent (25 April I806). The prototype of this harp is today conserved in the Gaveau-Erard-Pleyel archives, property of the AXA insurance group, on long-term loan to the Association Ad Libitum, Etobon, France.

6 Erard's system of rotating tuning pins was a double-action version of the single-action harp with rotating tuning pins invented by Cousineau and the Belgian engineer Michel-Joseph Ruelle. The request for their patent dates from 7 February 1799, and Georges Cousineau and his son Jacques-Georges (I760-1836) continued to refine this system until April I8O2. 
a continued downward pedal motion could produce the subsequent tightening of the same string.

Erard refrained from marketing the double-action harp with rotating tuning pins, and produced only one prototype, realising that the intonational problems present on Cousineau's single-action version of the harp with rotating tuning pins were exacerbated on an instrument whose strings had to be wound to not one very precise point, but two. ${ }^{7}$ Erard would eventually abandon the system of rotating tuning pins, but he would retain the double notches in the pedal box, an innovation for which this instrument was the first example (see Figure I). ${ }^{8}$

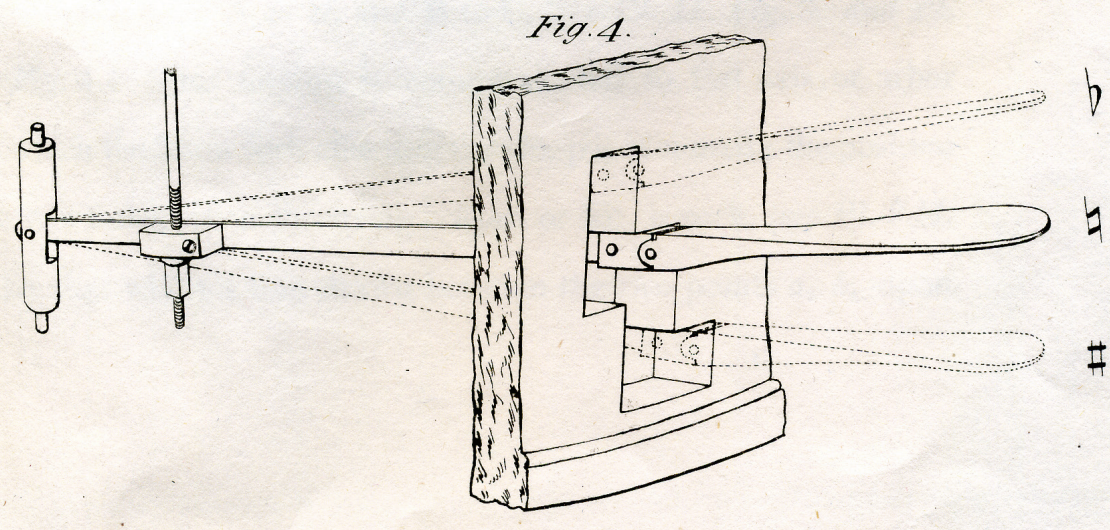

Figure 2. Erard's double-notched pedal box (I80o). The three positions correspond to the three notes that can be produced on each string: flat (open string), natural (first notch) and sharp (second notch). Drawing from Pierre Erard, The harp in its present improved state compared with the original pedal harp, London I82I.

By 1807, Erard had invented a second double-action harp model, which once again featured his double-notched pedal box from I80o. Still hoping to avoid having to resort to a double row of mechanism, he linked the pedals to a new invention resembling a forked disc, but which Erard referred to as a 'newly-invented apparatus for stopping the string' (in the French version of the patent, he referred to the mechanism as 'fourchettes'). When the harpist presses the pedal to the first position, the apparatus turns to allow the top fork pin to press against the string while a newly-invented 'rising part' presses the opposite side of the string from above, stabilising the string as the semitone modification from flat to natural is produced. When the

7 Precise intonation was an important focus of Erard's work. His forked disc patent includes adjustable nuts for the fine tuning of the semitones.

8 In a French patent from this period (requested on 27 January I806, and granted on 25 April I806), Erard appeared to still consider the rotating tuning pins to be a viable system. 
harpist moves the pedal to the second position, the apparatus turns still further, allowing the bottom fork pin to press against the string at a lower point, and using the top fork pin as the stabilising force on the opposite side, as the second semitone modification from natural to sharp is sounded. ${ }^{9}$

Although Erard would protect this new invention by patents in both London and Paris, he quickly abandoned work on it because his attention was attracted by Gröll's new patent, which consisted of a double row of forked discs, an idea that would become essential to his resolution of the problem of the double action. ${ }^{10}$

\section{GRÖLL AND HIS PATENT}

By the end of the eighteenth-century, Karol Gröll (see Figure 3) had earned a reputation as one of Warsaw's finest artists, working principally as an engraver for his father, the printer Michał Gröll (1722-98). ${ }^{\text {II }}$ Following his father's death, Karol sold his family printing firm and pursued his career abroad. In I804, he arrived in London, settling in Leicester Fields (today Leicester Square) in the city's West End, and partially anglicised his name as Charles Gröll. During his first years in London, he supported himself as an engraver and miniature portraitist. He soon turned his attention to chemical and mechanical inventions, selling patents to those who had the necessary manufacturing infrastructure to make use of them; as one example, he invented a porcelain paint that earned him I,Ooo Polish ducats. ${ }^{12}$

9 No harps with this mechanism have been identified, and none seem to have been sold, but one can assume that at the very least a prototype must have existed, since the Erards had important harp workshops in both Paris and London.

IO Erard submitted a patent request for this invention in London on 24 September I808 (granted on 24 March I809). He then sent it to his brother Jean-Baptiste, who on 3I May I809 submitted a request for a French patent, which was granted on 7 July I809.

II In I802, the Polish painter Aleksander Orłowski included Gröll in a group portrait representing eight of the most illustrious artists in Warsaw. See Aleksander Kraushar, Karol Gröll, rytownik i szkic rysunkowy artysty-malarza Aleksandra Ortowskiego z roku I802 [Karol Gröll, engraver and sketch drawing by artist-painter Aleksander Orłowski from I802], Warsaw I9II. The National Museum in Warsaw holds a number of paintings and engravings by Gröll.

I2 The principal sources of information on Gröll's life and career, on which virtually all subsequent publications on Gröll are based, are Antoni Magier, Estetyka miasta stotecznego Warszawy [Aesthetics of Warsaw, capital city][manuscript text from I833], ed. Juliusz W. Gomulicki, Wrocław 1963, pp. 43, 245-246 and 4I2, and Hipolit Skimborowicz, 'Karol Grell', Gazeta Warszawska 2II (August I857), pp. 5-6 and 2I2 (August I857), pp. 5-6. Skimborowicz compiled an encyclopaedia of Polish scientists, writers and artists in 17 volumes, but his unpublished manuscript was destroyed during the Second World War. Kraushar's aforementioned book (see fn. II) only treats Gröll's engraving activity. For more on Gröll's life and varied career, see: Hanna Widacka, 'O sztuce rytowniczej Karola Michała Grölla' [About Charles Gröll's art of engraving], Rocznik Warszawski 25 (I995), p. 74; Michał Kleofas Ogiński, Listy o muzyce [Letters about music], Kraków 1956, pp. IOI-IO2; and Stownik artystów polskich i obcych w Polsce dziatających: malarze, rzeźbiarze, graficy [Dictionary of Polish and foreign artists in Poland operating: painters, sculptors, graphic artists], vol. 2, Warsaw 1975, pp. 477-479. 


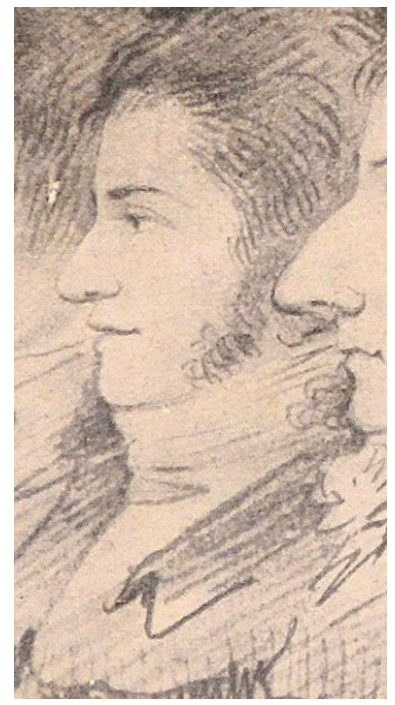

Figure 3. Portrait of Karol Gröll in I802. Detail from group portrait by Aleksander Orłowski. Photo: National Library of Poland, Warsaw.

There is no evidence that Gröll had any prior involvement with musical instruments, but sometime between 1804 and I807, Gröll learned of Erard's aborted I800 attempt at a double-action harp, most likely by consulting a copy of the patent, since the sole example of the instrument was the prototype in Erard's workshop. ${ }^{\mathrm{I3}}$ Gröll had the idea of linking Erard's double-notched pedal box to a double row of mechanism on the neck of the harp, similar to that present on Cousineau's fourteen-pedal instrument. In order to connect the pedals to the mechanism, Gröll used a spring and a system of rollers, different from anything Erard had used, or would ever use. On I3 July 1807, Gröll submitted his patent to the London Patent Office. English patent law required that the applicant submit the detailed specifications for the patent within six months, which Gröll did and on II January I808 his patent entitled 'Certain improvements upon harps' (no. 3059) was granted (see Figure 4). ${ }^{\text {I4 }}$

I3 Magier and Skimborowicz (op. cit., see fn. I2) posited a connection between Gröll and Michał Kazimierz Ogiński (c. 1730-I800), author of the 1765 article on the harp in Diderot and D'Alembert's Encyclopédie. Magier wrote that Gröll attributed the invention of the single-action harp to Ogiński, not knowing that it had been invented much earlier by Hochburcker. Ogiński never claimed to have been involved in harp innovations or manufacture. Several factors render it unlikely that Ogiński and Gröll collaborated on Gröll's patent before Gröll arrived in London. First, the patent includes Erard's double-notched pedal box, which would have been unknown outside of post-I8or London. Second, had Gröll prepared the patent prior to his arrival in London in 1804 , he would not have waited until 1807 to submit it. Ogiński is sometimes confused with his nephew, the composer Michał Kleofas Ogiński (1765-I833).

I4 Gröll's patent drawings show a slightly anachronistic scroll-top harp, which by the early nineteenth century had been supplanted by a capital design initiated by Sébastien Erard. However, many scroll-top harps would have still been in use in 1807 . 


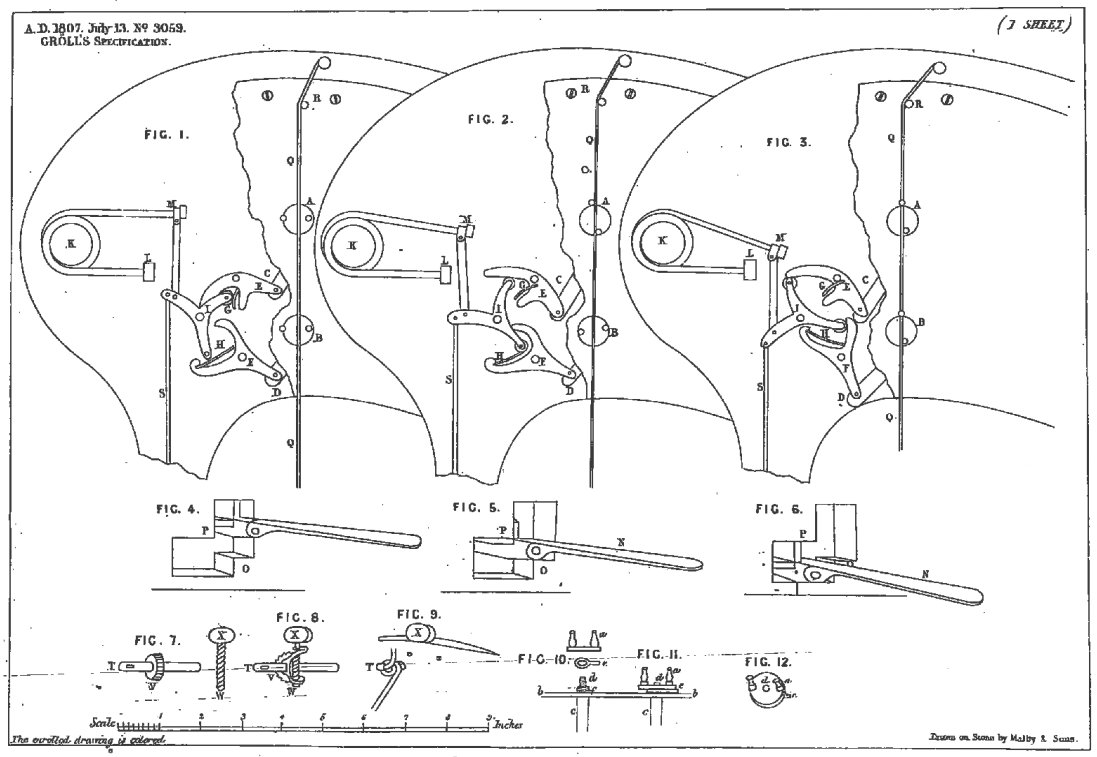

Figure 4. Drawing from Gröll's I808 patent, showing (from left to right) the three notes produced by each string: flat, natural and sharp. The string passes through Erard-style forked discs, and Erard's double-notched pedal box is shown in the middle of the drawing. Photo: The British Library.

Gröll intended from the start to sell his patent, as he was not an instrument maker and lacked the means necessary to manufacture harps. In his patent, Gröll claimed that his invention could work with double rows of any sort of mechanism (forked discs, crotchets or rings), which would have allowed him to approach a variety of London harp makers to sell the rights to his invention to the highest bidder.

The Erard family was well informed of new patent requests, in both London and Paris, often before the actual submission. Sometimes the Erards were alerted to a new patent by the London patent office, who sought to know if the proposed patent would be opposed by existing patent holders for similar inventions. For example, in 1817, Pierre Erard (1794-I855), who directed the London branch of the Erard firm from I8I4 until I855, wrote to his uncle Sébastien: 'I received information from M. Pole of the patent office that M. Dizi is pursuing a patent for certain improvements upon harps, M. Pole

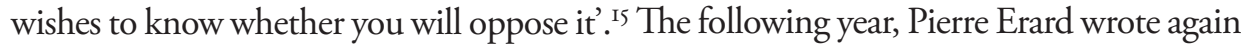
to his uncle 'Someone named Willis, whom I had never heard of, is requesting a patent

I5 Erard is referring to the Belgian harpist François-Joseph Dizi (I780-I840). Letter of 25 July I8I7 from Pierre Erard in London to Sébastien Erard in Paris; see HEPH, vol. 2, p. 66r. The original text of the passage cited from the letter is in English. See also letters of I6 December 1817, 7 October I8I8, 9 March I819, 23 March I8I9, 28 April I8I9, 9 July I8I9, 23 February I820, 9 January I82I, I5 January I82I, 5 February I822, 6 February I 822 and 30 November I 824 from Pierre Erard in London to Sébastien Erard in Paris; see HEPH, vol. 2, pp. 672, 693, 710, 71I, 714, 723, 731, 751, 754, 786, 787 and 829. 
for certain improvements upon the harp. ${ }^{.6}$ The Erards also had a network of unofficial informants who would alert them about competitors' patent requests. For example, in I822, Pierre Erard was able to see the technical drawings for a patent application by the harp maker Delveaux, because the artist hired to make the drawings was a friend of his. ${ }^{17}$

Sébastien Erard probably learned of Gröll's patent request in November 1807, while he was in Paris. He appeared to have been caught off guard by this innovation from an unknown competitor, and announced to his family that urgent business compelled him to depart for London, where he had not set foot since $1796 .^{18}$ Upon his arrival in London, Erard took immediate action on two fronts: buying the rights to Gröll's patent, and quickly submitting a patent request to protect his second double-action harp model with 'newly-invented apparatus for stopping the string' (see above). ${ }^{19}$ At that point, Erard probably did not know how his work would proceed over the following two years, and was doing all he could to keep his options open.

There has been confusion as to the amount Erard paid Gröll for the patent. Harp historian Mike Baldwin, for example, writes that the price was 'between Io,000 and 30,000 Polish red zlotys (depending on source)'. ${ }^{20}$ Leaving aside the gross discrepancy between these amounts, Gröll and Erard were living in London, and Erard's payment would therefore have been made in British pounds, not in Polish currency. The sources of information about the payment come from nineteenth-century Polish accounts, which give an approximate equivalence in Polish currency in order to convey to a Polish readership an idea of the sum in question. However, these Polish sources cite markedly different monetary units: the Polish złoty and the red złoty or ducat (equivalent to I8 Polish złotys). The architect Bolesław Podczaszyński wrote that Erard paid Gröll 30,000 Polish złotys, while the writer and physicist Antoni Magier claimed that the amount was I0,000 red złotys (which is six times greater than 30,000 Polish złotys). ${ }^{21}$

I6 'Un nommé Willis dont je n'ai jamais entendu parler sollicite une patente for certain improvements upon the harp' (translation by R.A.). Erard is referring to the harp maker Robert Willis. Letter of is October I8I8 from Pierre Erard in London to Sébastien Erard in Paris; see HEPH, vol. 2, p. 66I.

I7 Letter of 7 June 1822 from Pierre Erard in London to Sébastien Erard in Paris; see HEPH, vol. 2, p. 798.

I8 Letter of 17 November 1807 from Sébastien Erard in Paris to Elise Erard in Paris. Private collection. Correspondence from this period is scarce, but it appears that Erard returned to Paris sometime prior to April I808, only to depart once again for London on 30 June I808, arriving on 26 July I808. Letter of 23 April 1808 from Sébastien Erard in Paris to Madame de Chavagnac in Paris. Catalogue of public auction by Binoche and Giquello, Paris, 8 February 20I6, lot 46, and letter of 13 November I808 from Jean-Baptiste Erard in Paris to Sébastien Erard in London.

I9 Proof of Erard's purchase of Gröll's patent is found in several letters from Pierre Erard in London to Sébastien Erard in Paris: of 8 March I820, 7 July I820 and Io June I823; see HEPH, vol. 2, pp. 737, 747, 748 and 806.

20 Baldwin's information on the amount paid by Erard came from a now lost electronic publication by the harpist Liliana Osses Adams, The origins of the harp, California, February 2004, http://www.zwoje-scrolls. com/zwoje38/texto6p.htm, accessed 2 September 2009.

2I A. Magier, op. cit., pp. 245-247; H. Skimborowicz, op. cit., Gazeta Warszawska 2II, pp. 5-6. Skimborowicz cites notes about Gröll in an unidentified volume of Bolesław Podczaszyński, Pamiętnik Sztuk Pięknych [Diary of fine arts], Warsaw 1855 . 
In his I857 obituary for Gröll, Hipolit Skimborowicz stated that Magier's figure was erroneous, indicating that the correct figure was approximately 30,000 Polish złotys.

This amount would have been equivalent to between $£ 700$ and $£ 800$, an enormous sum at the time. By way of comparison, the annual rent for the Erard firm's London premises was $£$ I2 7 and the average weekly wages for the totality of his sixty workers was $£ 44$. The figure of between $£ 700$ and $£ 800$ corresponds to several large cash disbursals that the London branch of the Erard firm made to Erard in August and September I808, immediately after his arrival in London..$^{22}$

A manufacturer buying the rights to an inventor's patent was as common in early nineteenth-century London as it is in early twenty-first century Silicon Valley. ${ }^{23}$ Patent historian Harold Dutton has determined that almost a quarter of all patents litigated in London between I830 and 1849 had been 'assigned' (bought). ${ }^{24}$ In addition, he found that in the metal pin industry in London between 1800 and I835, virtually all the significant patents were granted to inventors working outside the industry. ${ }^{25}$

Patent assignment was such a common practice that it found its way into the Erard firm's business operations. In I82I, when Sébastien Erard was perfecting his revolutionary double-escapement action for the piano in Paris, Pierre Erard informed him about a conversation he had with the pianist Frédéric Kalkbrenner (I784-I849) concerning the London piano making firm of Collard \& Collard: 'I see from what Kalkbrenner said, this Collard might very well want to buy your patent! To sell it for a good price might be what you would like more than anything! There is no doubt that there would be buyers!' ${ }^{26}$ As it turns out, the Erards decided to build pianos in their own London workshop, but the fact that they had considered the idea of selling their precious invention to a competitor underscores the currency of the practice at the time. Similarly, the Erards were approached by inventors wanting to sell them patents. In 1820, for example, the harp maker John Charles Schwieso tried to sell the Erards his new patent, as Pierre Erard reported to his uncle: 'You think it is funny

22 The monetary equivalences in francs and pounds are calculated based on a gold parity value of the time. For more on Polish currency of the period, see Norman Davies, God's playground: A history of Poland, Oxford 2005, pp. IO3-IO4 and Grzegorz Wójtowicz, The origin and history of the Polish money, Warsaw 2006. For the amounts paid by the London branch of the Erard firm to Sébastien Erard in the summer of I808, see Erard 'London workshop notes', Erard London harp ledgers, vol. I, Museum of Music, Royal College of Music, London, RCM 497.

23 For a comprehensive study of patent sales in early nineteenth-century London, see Sean Bottomley, The British patent system during the Industrial Revolution, I700-I852: From privilege to property, Cambridge 20I4, pp. 202-229.

24 Harold Dutton, The patent system and inventive activity during the Industrial Revolution: 1750-1852, Manchester I984, p. I25.

25 Ibid., p. 126.

26 'Je vois que d'après ce que Kalkbrenner m'a dit, ce Collard pourrait bien avoir envie d'acheter votre patente! La vendre pour un bon prix serait peut-être ce que vous aimeriez le mieux! Il n'y a pas de doute qu'il se trouverait des acheteurs!' (translation by R.A.). Letter of I9 January I82I from Pierre Erard in London to Sébastien Erard in Paris; see HEPH, vol. 2, p. 756. 
that Schwieso came to me to propose to buy his invention, which he says is a marvellous thing! I told him, as you would imagine, that you have enough inventions and that you are not looking for any others!'27 In I838, Pierre Erard bought the rights to a piano patent from the Parisian builder Frédéric Maher. ${ }^{28}$

Manufacturers did not always buy patents with the goal of producing the invention in question. Often a firm would buy patents in their domain of activity in order to avoid any possibility of future legal challenges to their own products. As one nineteenth-century English patentee remarked: 'It is always cheaper to buy a bad thing, and have it of one's own, than it is to litigate it'. ${ }^{29}$

Erard purchased the rights to Gröll's patent in order to avoid troublesome legal oppositions to his own invention, not to actually build harps according to Gröll's model. The correspondence between Pierre and Sébastien Erard makes it abundantly clear that they considered Gröll's invention 'impractical' and 'impossible to make', noting that 'it was never put into practice'. ${ }^{30}$ When in I82I, Schwieso invented a new double-action harp based on Gröll's patent, Pierre Erard sent a detailed critique of the mechanism to his uncle Sébastien, pointing out the problems due to the excessive friction in the moving parts:

Its mechanism is a duplicate of Gröll's, that with the two forks. The first movement is operated by the friction of a rounded piece on a lever fitted at the end of a small pulley rotating on its axis. When the first movement is made, the piece that pushed against the pulley is concentric with the lever on which the pulley is mounted, so that this surface rubs against the pulley without disturbing the initial pressure on the forks in this way [Erard sketches the mechanism]. I will let you imagine the kind of effect this kind of escapement produces. And it does not even have the merit of novelty, because it is the same as what Gröll has done, except that here the part that rubs on the pulley is convex and for Gröll it is concave. ${ }^{3 \mathrm{I}}$

27 'Vous rirez en apprenant que Schwieso est venu me proposer d'acheter son invention, qu'il dit être une chose merveilleuse! Je lui ai répondu, comme vous le supposez, que vous aviez assez de vos inventions sans chercher celles des autres!' (translation by R.A.). Letter of 7 March 1820 from Pierre Erard in London to Sébastien Erard in Paris; see HEPH, vol. 2, pp. 735-736.

28 Paris, Archives nationales, ET/LXV/69o.

29 'Questions addressed to the Committee to John Lewis Ricard, Esquire, a Member of the House of Commons, and his Answers thereto', in: House of commons papers, vol. I8, London I851, p. 394.

30 'impraticable [...] inexécutable [...] n’a jamais été mise à exécution’ (translation by R.A.). Letters of 8 March 1820 and 7 July I820 from Pierre Erard in London to Sébastien Erard in Paris; see HEPH, vol. 2, pp. 737 and 747.

3I 'Son mécanisme est une copie de celui de Gröll, celui des deux fourchettes. Le premier mouvement est opéré par le frottement d'une pièce arrondie sur un levier muni à l'extrémité d'une petite poulie tournant sur son axe. Lorsque le premier mouvement est opéré, la pièce qui a poussé contre la poulie devient concentrique avec le levier sur lequel la poulie est montée, en sorte que cette surface frotte sur la poulie sans déranger la première pression des fourchettes de cette manière. Je vous laisse à penser l'effet que doit produire un pareil échappement. [drawing] Et cela n'a même pas le mérite de la nouveauté, car c'est la même chose que Gröll, excepté qu'ici la pièce qui frotte sur la poulie est convexe et chez Gröll elle est concave' (translation by R.A.). Letter of 2 March I82I from Pierre Erard in London to Sébastien Erard in Paris; see HEPH, vol. 2, p. 760 . No Schwieso harp with the Gröll mechanism has yet been identified. 
The Erards did not deem it necessary to sue Schwieso for patent infringement, considering that the poor quality of his Gröll model harp would bring about its own demise.

After becoming the rightful owner of Gröll's patent, Erard worked for almost two more years before submitting his next patent for a double-action harp on 2 May I8IO. This new patent consisted of a double-notched pedal box linked to a double row of forked discs - as in Gröll's patent - but with an entirely different system linking the pedals to the mechanism (see Figure 5). Moreover, in Erard's patent, the discs can turn independently from one another, which does not appear to be the case on Gröll's invention. Erard also displaced the mechanism for the upper notes to allow for more room for the harpist's hands between the soundboard and the neck, added an adjustment for the pedal's fulcrum and designed a collar and socket system in which the tuning pins are inserted in order to allow them to move more smoothly.
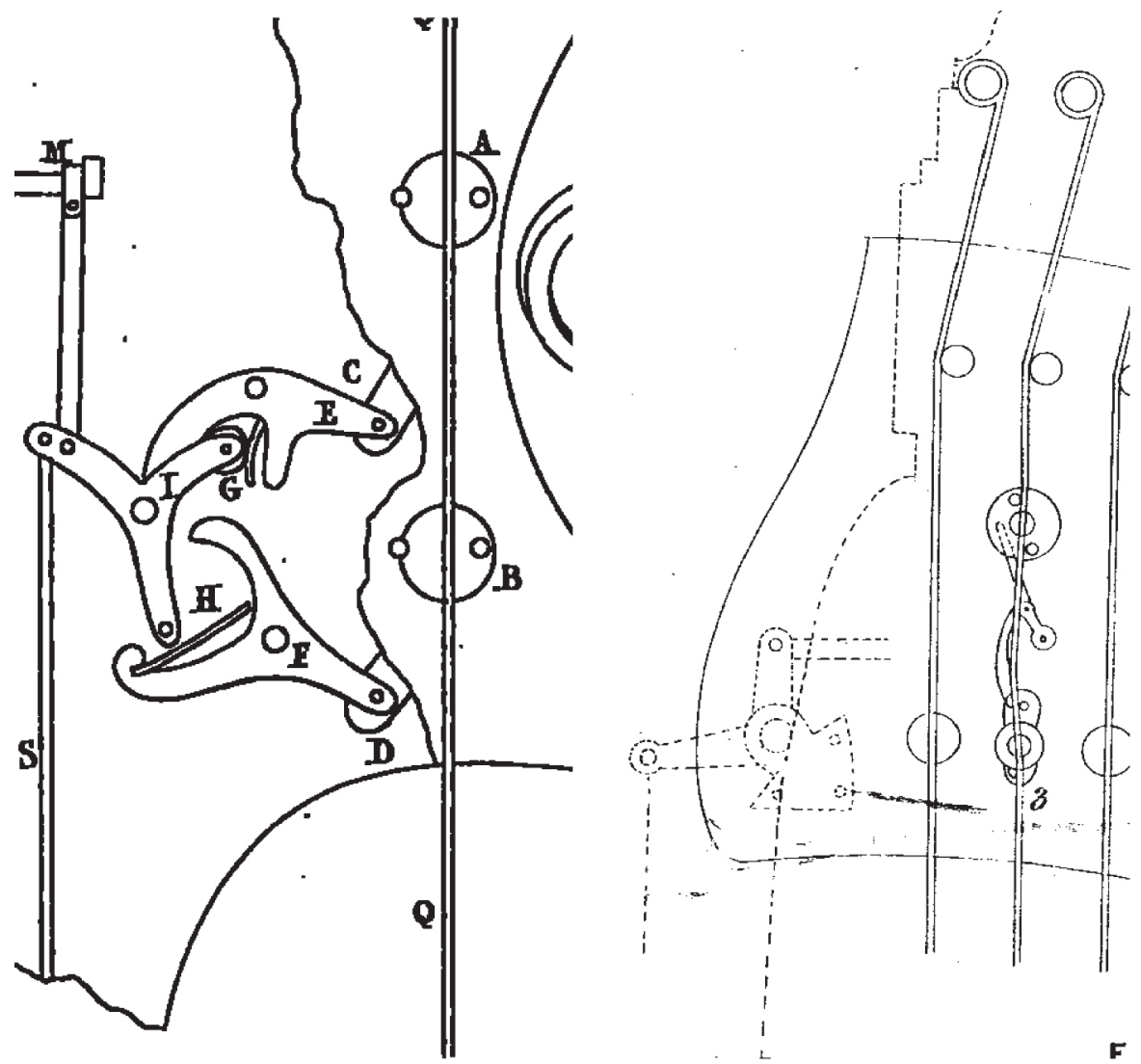

Figure 5. Left: detail from Gröll's I808 patent. Right: detail from Erard's I8Io patent. In both cases, one can see the string passing through the two forked discs, and the very different linkage mechanisms inside the neck of the harp, shown on the far left of each drawing. Photos: The British Library. 
Erard's patent (no. 3332) was granted on 2 November 1810, and shows a system close to the one that is used on harps today (see Figure 6). Eager to protect their new invention on the continent, Sébastien's brother Jean-Baptiste Erard (1749-1826) quickly submitted the same patent in Paris. ${ }^{32}$ In the introduction to their patent, Jean-Baptiste boldly claimed: 'The Erard brothers [...] dare say that they have arrived at the summit of perfection of this instrument, on which one can play all piano music, as on the piano itself, which was not possible before..$^{33}$
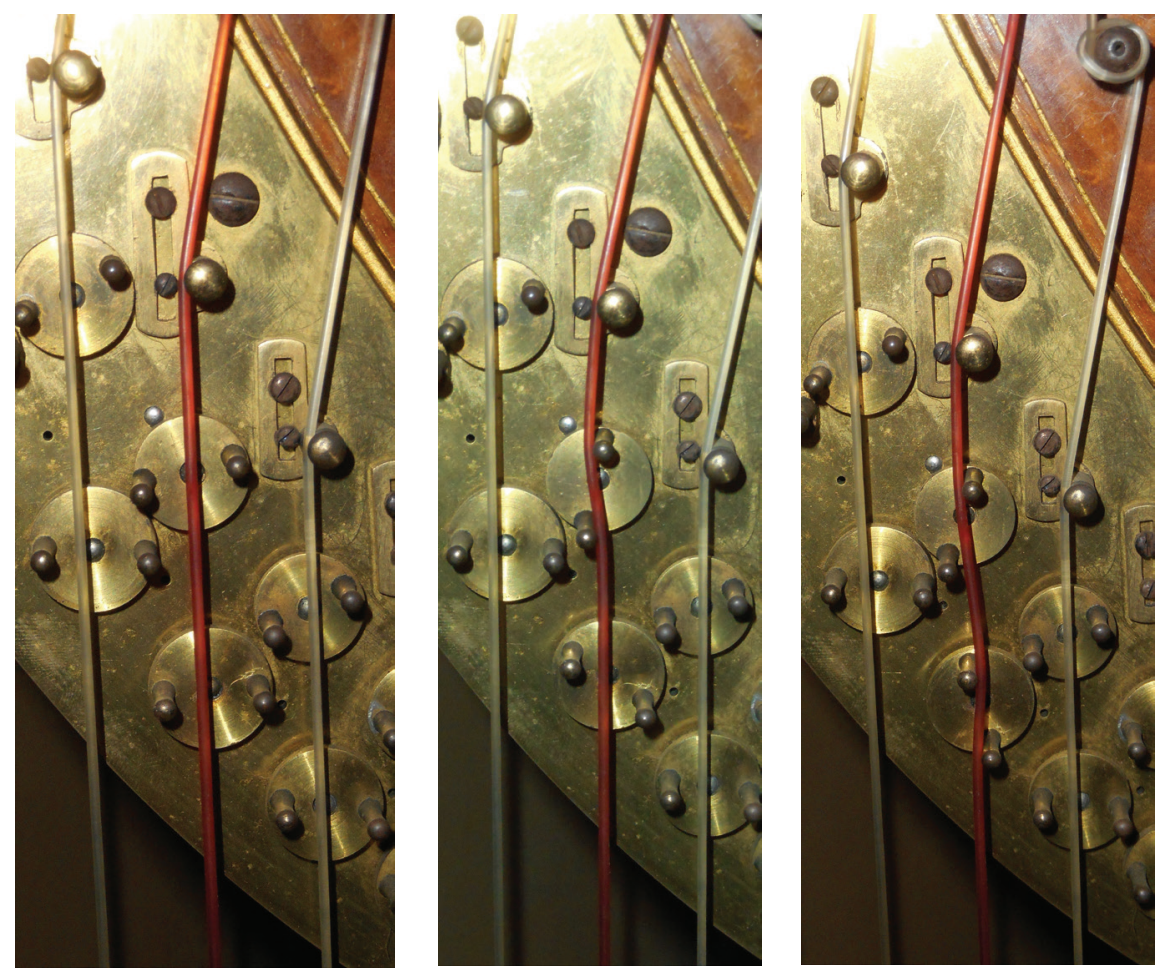

Figure 6. Forked discs on an Erard double-action harp. Left: the red C string is in open (flat) position. Centre: the $\mathrm{C}$ pedal has been placed in the first notch, turning the top fork of red $\mathrm{C}$ string to the natural position. Right: the $\mathrm{C}$ pedal has been placed in the second notch, turning the bottom fork of red $\mathrm{C}$ string to the sharp position. Photo: Robert Adelson.

32 The patent was submitted on 23 February I8II, and granted on IO August I8II, with an addendum submitted on 2 September I8I3 and granted on 28 February i8I5. See also Rainer Thurau, 'Die Harfenmechanik Erards - ihre Funktion und Restaurierung', in: Sébastien Erard: ein europäischer Pionier des Instrumentenbaus. Internationales Erard-Symposium Michaelstein I3.-I4. November 1994, ed. Rudolf Frick, Blankenburg 1995 (= Michaelsteiner Konferenzberichte 48), pp. 28-29.

33 'les frères Erard [...] osent se flatter d'être arrivés au dernier degré de perfection de cet instrument, sur lequel on pourra jouer toute la musique de fortepiano, comme sur le piano même, ce qui ne pouvait l'être, avant' (translation by R.A.); see Les frères Erard, Brevet d'invention et de perfectionnement de Is ans: mécanisme destiné à être adapté aux harpes et servant à faire les bémols et les dièses, IO August I8II, p. 2. 
As time passed, however, the purchase of Gröll's patent became a thorn in the side of the Erard firm, because it called into question their confidence in the proprietary claim to their own inventions. In I820, for example, Pierre Erard hoped to sue the numerous harp makers in London who were making double-action harps with two rows of forked discs, but asked his uncle: 'Does the principle of the two forks set into motion by a single pedal belong to you? That is the question [...]. It is a very important question of whether, by using a mechanism different than yours, one can make double-action harps with two forks! This is a principle to refute, as it seems to be spreading, by all these falsifications!'34

Pierre Erard was especially concerned that by suing his rivals, it would give them the opportunity to argue in court that Gröll's patent preceded Erard's. Even more worrisome, the only proof Pierre could find of his uncle's transaction among the papers of the London branch of the Erard firm was a letter from Gröll to Sébastien Erard in which Gröll committed to selling the patent. ${ }^{35}$ Pierre assumed that in order to make this sale official, Sébastien should have taken the additional step of having the patent assignment ratified by the Patent Office. In this, Pierre was most likely incorrect, his mistake deriving from his experience with French patent law, where the assignment ('cession') of a patent had to be ratified by registering it with the local prefecture. ${ }^{36}$ Even this step was often overlooked by French inventors, but in England it was entirely unnecessary. Nevertheless, Pierre claimed that the surest way to avoid problems related to Gröll's patent would be to have it annulled by arguing that it would be impossible to make a functional harp according to Gröll's patent description.

Pierre Erard's worries about Gröll's patent returned in his I823 lawsuit against the London harp maker Edward Dodd (I79I-I843), who, like Schwieso, continued to build double-action harps with forked discs without a patent. Pierre obtained a legal injunction against Dodd, and planned to sue for damages on the 'forty or so harps' Dodd had built on Erard's model. ${ }^{37}$ Pierre worried, however, that Dodd might try to defend himself by bringing up the anteriority of Gröll's patent. Pierre alleged that Gröll's patent should be nullified because Gröll was not the first to have the idea of a double row of mechanisms, as Cousineau had already done so. Pierre therefore asked

34 'Les deux fourchettes mises en action par une seule pédale vous appartiennent en principe ? Voilà la question [...]. C'est une question fort importante de savoir si, au moyen d'un autre mécanisme que le vôtre, on peut faire des harpes à double mouvement avec deux fourchettes! C'est un principe à réfuter, car il semble, par toutes ces contrefactions, s'établir!' (translation by R.A.). Letters of 29 March I820 and 7 July I820 from Pierre Erard in London to Sébastien Erard in Paris; see HEPH, vol. 2, pp. 739 and 748.

35 This letter has not survived.

36 Victor Alexis Désiré Dalloz, Jurisprudence générale: répertoire méthodique et alphabétique de législation, de doctrine et de jurisprudence en matière de droit civil, commercial, criminel, administratif, de droit des gens et de droit public, vol. 6, Paris I847, p. 605.

37 'une quarantaine de harpes environ' (translation by R.A.). Letter of Io June 1823 from Pierre Erard in London to Sébastien Erard in Paris; see HEPH, vol. 2, p. 806. See also letter of 30 May I823 from Pierre Erard in London to Sébastien Erard in Paris; HEPH, vol. 2, p. 804. 
his uncle to send 'by the quickest means possible' the Cousineau fourteen-pedal harp..$^{38}$ This turned out to be unnecessary, because Dodd apologized to Erard, and the case was settled out of court. Nothing more is known about the role played by this Cousineau harp in the Erards' legal battles. If the harp was sent to London, it was at some point sent back to Paris, for it remained in the collection of the Erard firm until 1959. ${ }^{39}$

Erard's rivals did not allow him to forget Gröll's patent, using it to weaken the firm's reputation for innovation. For example, in I834, a laudatory article about the accomplishments of the Erard firm attracted the attention of the Belgian harpist François-Joseph Dizi (1780-1840), who had a rectification inserted in the newspaper, explaining that the invention of the double-action harp should not be attributed to Erard but rather to Gröll:

Sir, I was surprised to read in your newspaper on the second of this month that you attribute to Mr Sébastien Erard the invention of the double-action harp, one of the most remarkable achievements in musical manufacture. Without entering into a debate about the merits of this innovation, it is only fair that due credit goes to its author, and as a result I cannot let pass this opportunity to claim my rights to this invention, for which Mr Gröll and I were granted a patent in London in $\mathrm{I} 807$ [sic]. This patent is entitled Invention of the double-action harp by division. The privilege was bought shortly after by $\mathrm{Mr}$ Sébastien Erard, and it is thanks to this transfer that we made that he was able to modify, as he saw fit, the original invention. As I would like to believe, Sir, that you have been given incorrect information, I trust that your impartiality will allow you to insert my rightful claim in one of your next issues..$^{4}$

Pierre Erard understood Dizi's claim as a way to attack the Erard firm, and immediately challenged Dizi to a duel to defend the honour of the Erard family. In the end, Dizi apologized, probably saving his life, for Pierre noted that the experience taught him that he was very skilled at shooting with his pistol. ${ }^{41}$

As for Gröll, after selling his patent to Erard in 1808 , he remained in London for a few more years, continuing to patent innovations for musical instruments. In I8I2,

38 'par la voie la plus prompte' (translation by R.A.). Letter of 13 June 1823 from Pierre Erard in London to Sébastien Erard in Paris; see HEPH, vol. 2, p. 807.

39 R. Adelson, A. Roudier and F. Duvernay, op. cit., pp. I76-I77.

40 'Monsieur, Je vois avec surprise dans le feuilleton de votre journal du deuxième de ce mois, que vous attribuez à Monsieur Sébastien Erard l'invention de la harpe à double mouvement, un des perfectionnements les plus remarquables de l'industrie musicale. Sans apprécier ici le plus ou le moins de mérite de cette innovation, il est de toute justice qu'elle reste en entier à son auteur, et je ne puis par conséquent laisser passer cette circonstance sans revendiquer mes droits à cette invention, pour laquelle Monsieur Gröll et moi prîmes un brevet à Londres en 1807 . Ce brevet porte [le titre], Invention de la harpe à double mouvement par division. Le privilège en fut acheté peu de temps après par Monsieur Sébastien Erard, et c'est par suite de la cession que nous lui en avons faite, qu'il a pu modifier, à sa volonté, l'invention première. Comme j’aime croire, Monsieur, que vous avez été induit en erreur, j'ose espérer de votre impartialité que vous voudrez bien insérer ma juste réclamation dans un de vos prochains numéros' (translation by R.A.). 'Réclamation de M. Dizi concernant les harpes à double mouvement', Le Figaro 9 (II June I834) no. I52. Dizi exaggerated his own role in this invention, as his name does not appear on Gröll's I808 patent.

4I Letter of I July I834 from Pierre Erard in Paris to Céleste Erard in Berlin. Private collection. 
he was granted a patent (no. 353I) for the 'nail violin', a member of the family of friction idiophones. In 1813 , he and Dizi patented a new 'perpendicular harp', which was manufactured by Dodd. ${ }^{42}$ Around I8I4, Gröll returned to Warsaw, once again working as an engraver and an inventor. During this period he may have collaborated with the French émigré Philippe de Girard (I775-1845) on a piano with tremolo effect called the 'tremolophone'. ${ }^{43}$ Although he seemed to have abandoned instrument design during his final years, Gröll lived long enough to see the double-action harp adopted as the preeminent model around the world, which was perhaps a source of personal satisfaction, given the role he played in its development.

\section{CONCLUSION}

Did Sébastien Erard take credit for an invention that was not his, and can Gröll be considered, as some would suggest, the forgotten Polish inventor of the modern harp?

Gröll's patent is more heavily indebted to Erard's inventions than Erard's patent is to Gröll's. Indeed, the only elements from Gröll's patent that remained in Erard's I8ro patent were elements that had in fact been invented by Erard: the double-notched pedal box and the forked discs. Moreover, at the time that Erard bought Gröll's patent, both of these elements were still protected by Erard's patents from I794 and I8OI, respectively. Erard could have opposed Gröll's patent on these grounds, but decided that it would be safer to buy the rights to it, knowing that in lawsuits the complex technical issues were often considered by judges who 'understand neither mechanics nor music'. ${ }^{44}$ The linkage between the pedals and the forked discs was the weakest part of Gröll's patent, one that was conspicuously not adopted by Erard, undoubtedly due to the excessive friction inherent in its construction.

We will never know for certain how Gröll harps would have worked or stood the test of time, since they have never been built nor played. After all, a patent is not a detailed recipe for construction; it only gives the general outlines of an invention that an inventor wishes to protect. Even with respect to Erard's patents, the subtleties of the harps are not to be found in drawings or descriptions but in the instruments themselves. A harp built according to Gröll's patent would work in a basic sense: that is, it would be able to produce the two semitone modifications on each string. ${ }^{45}$ When applying such a system to a full harp under tension, there would probably be

42 On this instrument the harp's strings were attached not to the left side of the neck, but rather in the centre (thus the name 'perpendicular'). By this means, Gröll and Dizi hoped to give a more even distribution of the string tension, thereby limiting the structural deformations in the harp's frame.

43 H. Skimborowicz, op. cit., Gazeta Warszawska 2II, pp. 5-6. The Polish county and town Żyrardów are named in honour of Philippe de Girard.

44 'n'entendent pas la mécanique, ni la musique' (translation by R.A.). Letter of 9 March I8r9 from Pierre Erard in London to Sébastien Erard in Paris; see HEPH, vol. 2, p. 710.

45 In 2016, the Swiss harp maker Beat Wolf built a wooden model of part of Gröll's mechanism, an experiment that confirmed the system was capable of turning the forked discs. 
unwanted noise, particularly rubbing and squeaking in the metal rolls which push the gear levers. Moreover, Gröll's ideas about spring tension, position and sizes, and about the movement of levers to the rods are problematic, and his pedal box did not allow for the secure lodging of the pedal in its notch.

Neither Erard nor Gröll can be considered the first to invent a harp that can play in all keys, if their contributions are understood in a broader historical perspective. Chromatic harps had been present since the non-pedal multi-rank instruments of the Renaissance, and similar models reappeared at the end of the eighteenth century. ${ }^{46}$ Even in the history of the double-action pedal harp, from Cousineau's fourteen-pedal instrument through Erard's patents from I80I, I808 and I8Io, Gröll's model was the third to be invented, and the Erard model that is in general use today was the fifth.

Erard's I8ro patent has endured because it proved itself to be the first satisfyingly functional double-action system. This aspect of functionality should not be taken lightly, as the four previous double-action harp models (Cousineau's in 1782, Gröll's in 1807 and Erard's own in 1800 and 1808) failed precisely because the instruments were over-complicated, clumsy or unreliable. Convincing musicians who depended on their instruments for their livelihood to abandon the already functional single-action harp for a new double-action model was a monumental task that could only be undertaken with a mechanical system that worked perfectly.

It is impossible to know if Erard would have arrived at the solution found in his I8IO patent had it not been for Gröll. The trajectory of Erard's inventive work in the preceding decade, consisting of a progressive elaboration of the neck mechanism, suggests that he was heading inexorably toward Gröll's idea. Initially eschewing the double row of mechanism inherent in the Cousineau fourteen-pedal harp, Erard first tried a system with no mechanism whatsoever (the model with rotating tuning pins of 1800 ). He then conceded to using a single row of forks aided by an additional lever (the I808 patent). The next logical step would have been to return to the double-row of mechanism, linked to the double-notched pedal box. Gröll's patent might therefore have been a catalyst, inciting Erard to take that final step in the direction in which he was already moving.

It is of course also possible that Erard would not have arrived at this solution had it not been for Gröll's patent. In that case, Gröll's doubling of the forked discs can

46 Between 1787 and 1789 , Johann Martin Christian Bothe invented a chromatic harp without pedals, mounted with strings of different colours to indicate the diatonic and chromatic notes, as on a piano keyboard. This large harp failed to gain adherents, for the strings were placed too close together and it required learning an entirely new technique, different from that to which harpists were accustomed for the pedal harp. In I804 Georg Karl Pfranger, a doctor from the Thuringian town of Schleusingen, invented a different model of a fully chromatic harp, also without pedals. Like Bothe's harp, Pfranger's model had a single row of strings, white for natural notes and dark blue and red for chromatic notes. Despite the advantage of its five-octave range, it was also deemed too difficult to master; Curt Sachs, Das Lexicon der Musikinstrumente, Bremen 20Io, p. 8I. See also Pfranger, 'Verkaufpreis', Allgemeine musikalische Zeitung II (February I809), p. 330. Non-pedal multi-rank harps were once again revived at the end of the nineteenth century in the form of Pleyel's 'harpe chromatique'. 
be seen as a crucial step in the evolution of the double action, as long as one keeps in mind that Gröll's is a composite invention whose individual parts had all been invented by others: the double mechanism by Cousineau, and the double-notched pedal box and forked disc by Erard. In conclusion, if we continue to consider Erard the father of the double-action harp, we might at least allow for Georges Cousineau to be its spiritual godfather, and for Charles Gröll to be its Polish uncle.

\section{ORYGINALNOŚĆ I ZAPOŻYCZENIA: ROLA KAROLA GRÖLLA W WYNALEZIENIU HARFY PEDAŁOWEJ O PODWÓJNYM WCIĘCIU}

Sébastien Erard (1752-I83I) jest powszechnie uważany za ojca współczesnej harfy, częściowo z powodu wynalezienia (ok. 1786 r.) widełek, które skracają struny o pół tonu, ale przede wszystkim z powodu stworzenia w I8Io r. harfy pedałowej o podwójnym wcięciu, która pozwoliła harfistom grać we wszystkich tonacjach i jest w użyciu we wszystkich koncertowych harfach pedałowych od ostatnich dwustu lat.

Jednak model harfy Erarda był podobny do tego opracowanego przez urodzonego w Warszawie Karola Grölla (1770-I857), który złożył swój patent w I807 r., a więc prawie trzy lata wcześniej niż Erard. Co więcej, Erard kupił prawa do patentu Grölla przed sfinalizowaniem swojego własnego projektu. Z tych powodów już w XIX w. niektórzy krytycy kwestionowali jego prawa do podwójnego systemu zmiany wysokości dźwięku struny, sugerując, że jego prawdziwym wynalazcą był Gröll. Celem niniejszego artykułu jest wyjaśnienie roli Grölla przez umieszczenie go w kontekście kształtowania się idei Erarda, co stało się możliwe dzięki licznym źródłom, które niedawno ujrzały światło dzienne.

Gröll zawdzięcza więcej wynalazkom Erarda, niż Erard - Gröllowi. Faktycznie jedynym elementem od Grölla, który pozostał w patencie Erarda z I8ro r., są detale, które w zasadzie zostały wynalezione przez Erarda: pedały i widełki. Połączenie między pedałami i widełkami było najsłabszą częścią patentu Grölla, który ewidentnie nie został przejęty przez Erarda, niewątpliwie z powodu nadmiernego tarcia związanego z jego konstrukcją. Patent Erarda z I8ı r. przetrwał, ponieważ okazał się pierwszym satysfakcjonującym, funkcjonalnym systemem. Jednak podwojenie widełek przez Grölla może być postrzegane jako milowy krok w ewolucji systemu podwójnego wcięcia (nie zapominając jednakże, że na wynalazek Grölla złożyły się poszczególne części wymyślone przez innych: podwójny mechanizm przez Cousineau i podstawa z pedałami i widełki Erarda).

Podsumowując, jeśli nadal będziemy uważać Erarda za ojca harfy pedałowej o podwójnym wcięciu, możemy przynajmniej pozwolić, by Georges Cousineau był jego duchowym ojcem chrzestnym, a Karol Gröll - jego polskim wujem.

Przekt. Jolanta Guzy-Pasiak

Keywords / słowa kluczowe: Erard, Gröll, Cousineau, harp / harfa, instruments / instrumenty, Paris / Paryż, London / Londyn 
Robert Adelson is professor of music history and organology at the Conservatoire de Nice. He has served as curator of the collection of historical musical instruments at the Musée du Palais Lascaris in Nice (2005-2016) and of the Camac collection of historical harps at the Château d'Ancenis (since 2017). His books include The history of the Erard piano and harp in letters and documents, 1785-1959 (2 vols., Cambridge University Press, 2015), Erard, l'invention de la harpe moderne I8II-20II (Editions Nice Musées, 20II) and Women writing opera: Creativity and controversy in the age of the French Revolution (University of California Press, 200I). He is a member of the Board of Governors of the American Musical Instrument Society and of the supervisory committee of the Gaveau-Erard-Pleyel archives.

\section{Recently published books by Liber Pro Arte}

Ars musica and Its Contexts in Medieval and Early Modern Culture edited by Pawet Gancarcayle.

Music Migration in the Early Modern Age: Centres and Peripheries

- People, Works, Styles, Paths of Dissemination and Influence edited by Jolanta Gusy-Pasiak \& Aneta Markuszewska

iswydawnictwo@ispan.pl

\section{Seria „Ikonografia muzyczna. Studia i materiały”}

Tom 1: Z badań nad ikonografia muzyczną do 1800

$$
\text { Źródła - problemy - interpretacje }
$$

redakcja Pawet Gancarcayke

Tom 2: Muzyka w sztukach wizualnych $X I X-X X I$ wieku redakecja Jolanta Gusy-Pasiak

Tom 3: Music, Politics and Ideology in the Visual Arts edited by Pawet Gancarcaylk \& Dominika Grabiec 